\title{
Geotectonic evolution of late Cenozoic arc-continent collision in Taiwan
}

\author{
Louis S. Teng \\ Department of Geology, National Taiwan University, 245 Choushan Road, Taipei (Taiwan, China)
}

(Received February 25, 1989; revised and accepted December 12, 1989)

\begin{abstract}
Teng, L.S., 1990. Geotectonic evolution of late Cenozoic arc-continent collision in Taiwan. In: J. Angelier (Editor). Geodynamic Evolution of the Eastern Eurasian Margin. Tectonophysics, 183: 57-76.

The active collision between the Luzon arc and the Asian continent in the Taiwan area is investigated in terms of plate kinematics and geological records. Regarding plate kinematics, the tectonic evolution of the collision can be reconstructed by superimposing the paleopositions of Luzon arc on the pre-collisional Asian continental margin. Regarding geological records, the collisional history can be interpreted from the stratigraphy of the Coastal Range and the Western Foothills and from the diastrophism of the Central Range of Taiwan. By incorporating geological information into plate kinematics, it appears that the Luzon arc could have hegun overriding the Asian continental margin in the late Middle Miocene (about 12 Ma). In the Late Miocene, the impingement of the arc deformed part of the continental margin and might have caused metamorphism of part of the Central Range, but no distinct effects were produced in the sedimentary record. In Mio-Pliocene times (about 5 $\mathrm{Ma}$ ), the arc changed its direction of motion from north-northwesterly to west-northwesterly and began to override the continental margin rapidly. The accretionary wedge grew increasingly to emerge above sea level and feed continental detritus to the Luzon forearc basin and to induce foreland subsidence on the continental margin. In the early Late Pliocene (about 3 $\mathrm{Ma}$ ), the collision drastically uplifted the mountain ranges in northern Taiwan, which shed voluminous orogenic sediments into the forearc and foreland basins. As the collision propogated toward the west and the south, the forearc and foreland basins were progressively accreted to the collisional orogen which eventually grew up to its present configuration.
\end{abstract}

\section{Introduction}

Taiwan comprises an active mountain belt formed by the collision between the Luzon arc and the Asian continent (Biq, 1973; Chai, 1972; Bowin et al., 1978; Ho, 1986). In the last two decades, numerous studies have been undertaken on the geophysics and geology of the RyukyuTaiwan-Luzon area and these studies have contributed an important database for understanding the collision in Taiwan (Bowin et al., 1978; Chai, 1972; Cardwell et al., 1980; Chi et al., 1981; Eguchi and Uyeda, 1983; Ernst et al., 1985; Hamburger et al., 1983; Ho, 1982; Karig, 1973; Page and Suppe, 1981; Pelletier and Stephan, 1986; Shiono et al., 1980; Suppe, 1981, 1984; Teng and Wang, 1981; Tsai, 1978, 1986; Tsai et al., 1977). Despite the general acceptance of the arc-conti- nent collision, many basic issues remain controversial. For instance, the collision has been interpreted as resulting from impingement of the Luzon arc by northwesterly motion (Barrier, 1985; Chi et al., 1981; Karig, 1973; Page and Suppe, 1981; Suppe, 1981, 1984; Suppe et al., 1981) or north-northeasterly motion (Wang, 1976; Tsai, 1978; Chen and Wang, 1988), with clockwise rotation (Seno, 1977; Teng, 1986) or counterclockwise rotation (Fuller et al., 1983; Halloway, 1982; Pelletier and Stephan, 1986; Stephan et al., 1986). The onset of the collisional orogeny is inferred to have taken place in the Late Miocene (Karig, 1973; Pelletier and Stephan, 1986; Jahn et al., 1986), Early Pliocene (Chi et al., 1981; Lundberg and Dorsey, 1988; Teng, 1982), Late Pliocene (Teng, 1987a; Wu, 1978), or Plio-Pleistocene (Ho, 1988). The various arguments demonstrate the lack 
of agreement on the collisional process and call for more investigation. This study attempts to look into this subject from two independent approaches: plate kinematics and geological records. Plate kinematics offers a general view over the tectonic evolution of arc-continent collision and the geological information provides evidence and constraints for the collisional events. By integrat- ing the information obtained from these two sources, the acquisition of a more comprehensive conception of the arc-continent collision in Taiwan is intended.

\section{Geotectonic framework}

Taiwan is presently sitting on the boundary between the Philippine Sea plate and the Eurasian

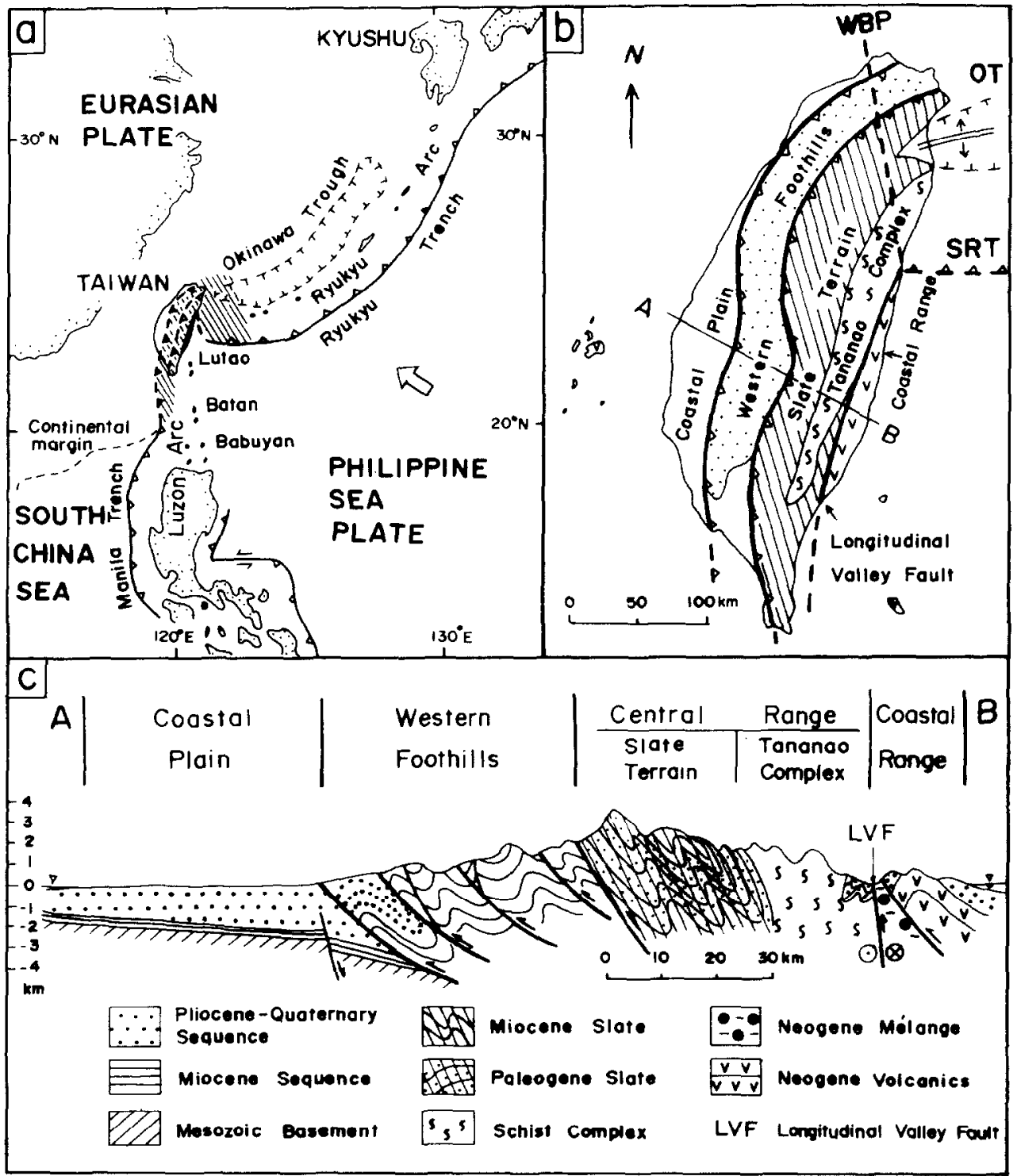

Fig. 1. Geotectonic framework of Taiwan. (a) Plate tectonic configuration of the Ryukyu-Taiwan-Luzon area. Shaded area shows the collisional orogen in the onshore (broken lines) and offshore (continuous lines) region. Modified from Ho (1986), Letouzey and Kimura (1986), Lewis and Hayes (1983, 1984), Sibuet et al. (1987), Stephan et al. (1986) and Suppe (1981). (b) Tectonic framework and geological terrains of Taiwan. Summarized from Bowin et al. (1978). Ho (1982), Liu and Wang (1982) and Tsai et al. (1977. 1981). $O T=$ Okinawa trough; $S R T=$ seismological Ryukyu trench; $W B P=$ western boundary of the subducting Philippine Sea plate. (c) Schematic cross section of Taiwan. Location shown in Fig. 1b. Summarized from Barrier and Angelier (1986). Chi et al.

(1981), Lee (1979), Meng (1967), Pelletier and Hu (1984), Stanley et al. (1981), Suppe (1980a), Tang (1977) and Yen et al. (1984). 
plate (Fig. 1a). The Philippine Sea plate is subducting beneath the Eurasian plate at the Ryukyu trench and overriding the crust of the South China Sea at the Manila trench. The SE-facing Ryukyu arc-trench system extends from southern Kyushu down to the east of Taiwan (about $123^{\circ} \mathrm{E}$ ) with associated subduction and backarc spreading extending further into northeastern Taiwan (Fig. 1b) (Bowin et al., 1978; Roecker et al., 1987; Sibuet et al., 1987; Tsai et al., 1977; Tsai,1986). The W-facing Luzon arc-Manila trench system (hereafter abbreviated to "Luzon arc-trench system") extends from southern Luzon up to about $22^{\circ} \mathrm{N}$ (Cardwell et al., 1980; Hamburger et al., 1983; Hayes and Lewis, 1984; Lewis and Hayes, 1984; Lin and Tsai, 1981) and merges into the mountain ranges of Taiwan further to the north. Taiwan is not only a collisional zone between the Luzon arc and the Asian continent but also a transform zone between the opposite-facing Ryukyu and Luzon $\operatorname{arcs}(\mathrm{Wu}, 1978)$.

The mountain ranges of Taiwan can be divided into two geological provinces by the Longitudinal Valley Fault, which is the geological suture between the coalesced Philippine Sea plate and the Eurasian plate (Figs. $1 \mathrm{~b}$ and c) (Ho, 1988). The Coastal Range to the east of the fault comprises volcanic and siliciclastic sequences of the accreted Luzon arc-trench system and the area west of the fault consists of metamorphic and sedimentary sequences of the deformed continental margin (Chai, 1972; Teng, 1987a). The Tananao metamorphic complex of the Central Range can be regarded as the unroofed continental besement and the Tertiary sequences of the slate terrain and the Western Foothills as the overlying sedimentary cover. In addition to the exposed part in Taiwan, deformed rock sequences of the collisional orogen can also be traced offshore to the accretionary wedge of the Manila trench to the south (Hayes and Lewis, 1984; Lewis and Hayes, 1984; Page and Suppe, 1981) and to the southern end of the Ryukyu arc to the northeast (Fig. 1a) (Letouzey and Kimura, 1986; Sun, 1989, and unpublished data). The coastal plain of western Taiwan and the offshore areas further to the west are underlain by mostly flat-lying Cenozoic sedimentary sequences which have not yet been deformed by the collision (Figs. 1c and 3) (Sun, 1982, 1985).

\section{Plate kinematics}

The kinematic reconstruction of the collision between the Luzon arc and the Asian continent is possible by first restoring the pre-collisional morphotectonic settings of the Asian continental margin and the travel path of the Luzon arc-trench system, and then superimposing the travel path of the Luzon arc on the pre-collisional Asian continental margin.

\section{Reconstruction of the Asian continental margin}

The present Asian continental margin near Taiwan can be divided into three parts, the Ryukyu arc-trench system and associated Okinawa trough, the Taiwan collisional zone, and the southeast China continental margin (Figs. 1a, 2 and 3). The Ryukyu arc-trench system has been developing on the Asian continent since at least the Early Miocene (Kizaki, 1986; Letouzey and Kimura, 1986; Shiono et al., 1980). The Okinawa trough is a nascent backarc basin which opened up in the Late Pliocene as a result of the collision in Taiwan (Lee et al., 1980; Letouzey and Kimura, 1986; Suppe, 1984; Viallon et al., 1986). To restore the pre-collisional Ryukyu arc-trench system, the Okinawa trough must be closed and the arc-trench shifted northwestward. By subtracting the amount of rifting estimated from seismic reflection studies (Kimura, 1985; Letouzey and Kiumra, 1986; Sibuet et al., 1987), the Late Miocene Ryukyu arc-trench system may be ascertained to have been about $80 \mathrm{~km}$ northwest of its present position (Fig. 2). The southern end of the pre-collisional Ryukyu arc is set at the southermost extension of the Miocene volcanics (Letouzey and Kimura, 1986) and at the easternmost end of the collision-deformed continental margin sediments (Fig. 1a).

The southeast China continental margin has been a rifted margin since the Cretaceous (Holloway, 1982; Ru and Pigott, 1986; Taylor and Hayes, 1980, 1983). As shown in seismic sections (Fig. 3) 


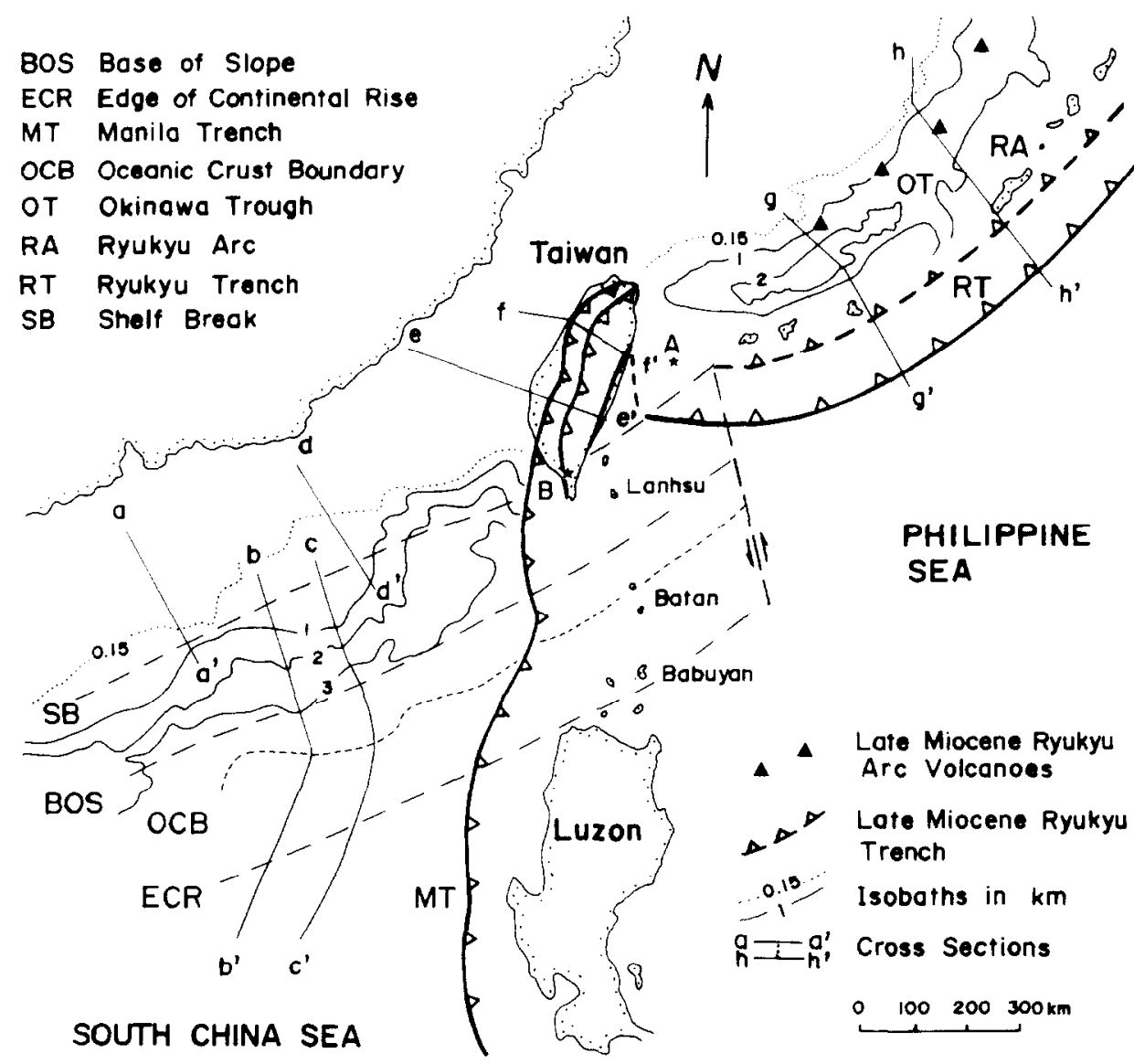

Fig. 2. Modern and reconstructed Late Miocene pre-collisional morphotectonic settings of the Asian continental margin near Taiwan Geological cross sections (a-a' to $h-h^{\prime}$ ) are shown in Fig. 3. See text for explanation.

(Ru and Pigott, 1986), this part of the continental margin is floored with an attenuated Mesozoic basement covered with late Mesozoic and Cenozoic sedimentary sequences. As far as the morphotectonic framework is concerned, the southeast China continental margin is characterized by well-developed shelf-slope-rise settings. The shelf break (SB) and the base-of-slope (BOS) can be approximated by the $200 \mathrm{~m}$ and $3000 \mathrm{~m}$ isobaths (Figs. 2 and 3). The outer edge of the continental rise (ECR) can be recognized from the seismic sections and the oceanic crust boundary (OCB) delineated on the basis of geomagnetic and bathymetric data (Bowin et al., 1978; Taylor and Hayes, 1983). Except for minor normal faulting, the Neogene-Quaternary sequence is not structurally disrupted, as shown in the seismic sections (Fig. 3 ). Hence, the morphotectonic settings of this part of the continental margin appear to have re- mained unchanged during Neogene-Quaternary times and can be regarded as the pre-collisional settings.

In the Taiwan collisional zone, the flat-lying Cenozoic sedimentary sequences and underlying rifted Mesozoic basement in Taiwan Strait represent the undeformed rock suite of the Asian continental shelf, similar to that of the southeast China continental margin (Bosum et al., 1970; Liu and Pan, 1984; Sun, 1982, 1985; Teng 1987a) (Fig. $3)$. In the Taiwan orogen, the original morphotectonic settings have been destroyed by the collision but facies characteristics and structural geological information on the deformed sequences allow partial reconstruction. By untangling the imbricated folds and thrusts in northern Taiwan (Suppe, 1980b), the Paleogene Szeleng Sandstone exposed in the northern slate terrain can be relocated $160-200 \mathrm{~km}$ southeast of its present posi- 

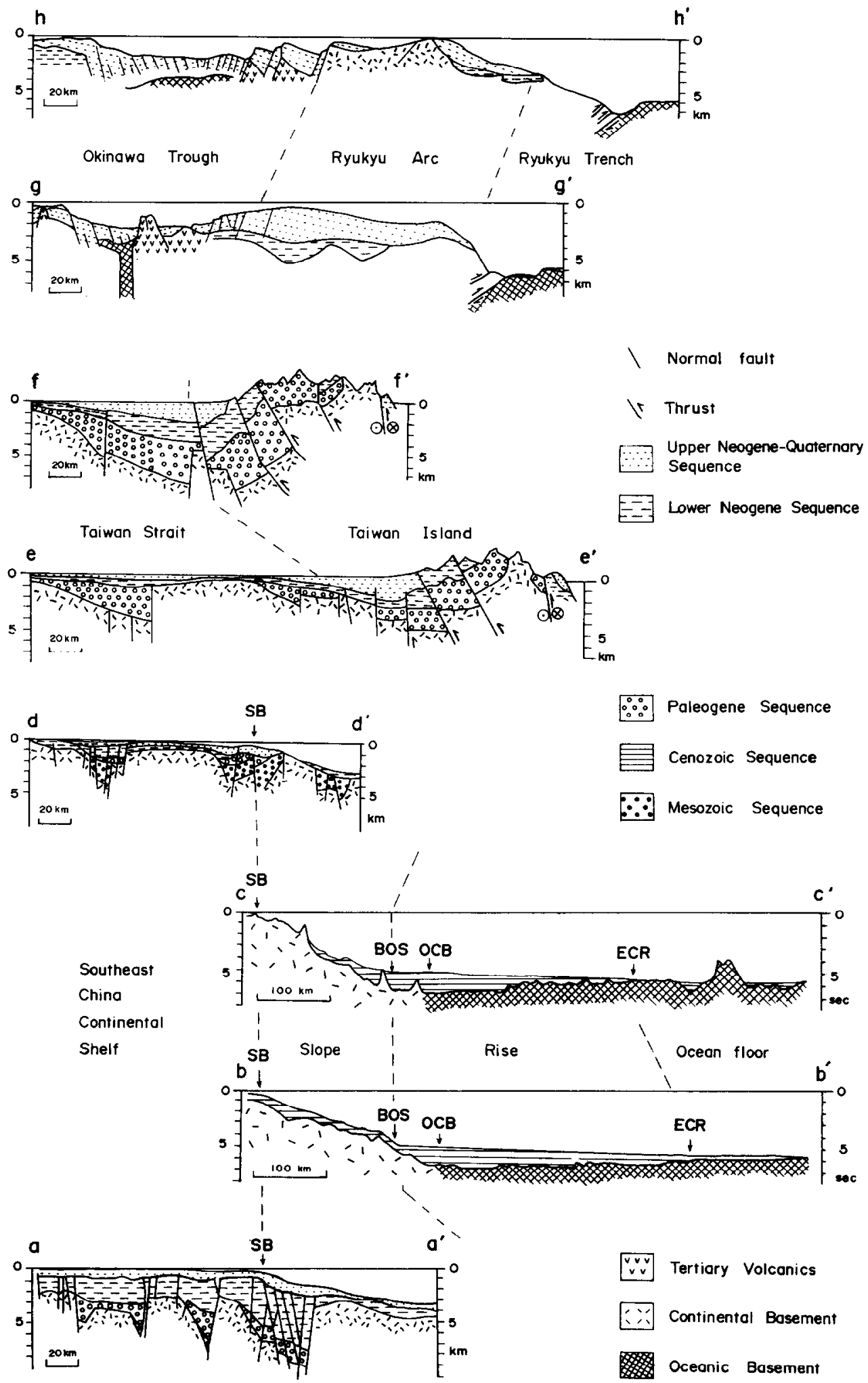

Fig. 3. Geological cross sections through the Asian continental margin near Taiwan. Locations and symbols are shown in Fig. 2. Modified from Ru and Piggott (1986) (a-a', d-d'), Taylor and Hayes (1980) (b-b', c-c'), Sun (1982) (c-e', f-f'), and Letouzey and Kimura (1986) (g-g', $\left.h-h^{\prime}\right)$. The structural complexities of the Taiwan orogen as shown in Fig. 1c are omitted in sections e-e' and $f-f$ for simplicity. 
tion (point A in Fig. 2). Since the Szeleng Sandstone is composed of coastal deposits accumulated on the original continental shelf, this point shows where the innermost limit of the pre-collisional shelf break was. In southern Taiwan, the outer shelf to upper slope deposits of the Late Miocene Lilungshan Formation (point B in Fig. 2) exposed on the west Hengchun Peninsula (Chen et al., 1985; Pelletier and Stephan, 1986; Sung, 1987) provide another control point for delineating the pre-collisional shelf break. By following these two control points, the pre-collisional shelf break of the southeast China continental margin can be extrapolated to Taiwan as shown in Fig. 2. So far, no control points for the pre-collisional base-ofslope, oceanic crust boundary, and outer edge of the continental rise can be obtained in Taiwan. Therefore, these lines are simply extrapolated from southeast China by paralleling the shelf break line. The reconstructed continental margin exhibits a rather simple morphotectonic pattern with the Ryukyu arc-trench system bordering the continental margin to the north and a rifted continental margin to the south. The boundary between the Ryukyu arc and the rifted continental margin is tentatively marked by a transform fault to accommodate the motion of the Luzon arc (Karig, 1973; Suppe et al, 1981).

\section{Backtracking Luzon arc}

The Luzon arc has been developing on the Philippine Sea plate since the Early Miocene or the Late Oligocene (Bachman et al., 1983; Balce et al., 1982; Karig, 1983; Richard et al., 1986). The Philippine Sea plate is presently rotating clockwise and moving toward the Eurasian plate at a speed of $7-9 \mathrm{~cm} / \mathrm{yr}$ due WNW in the Taiwan-Luzon area (Minster and Jordan, 1979; Ranken et al., 1984; Seno, 1977; Seno and Eguchi, 1983; Seno et al., 1987). Paleomagnetic data from DSDP cores (Kinoshita, 1980; Louden, 1977) and outcrops on the surrounding islands (Fuller et al., 1980, 1983; Haston et al., 1988; Hsu, et al., 1966; Jarrard and Sasajima, 1980; Keating and Helsley, 1985; Kodama et al., 1983; Larson et al., 1975; McCabe et al., 1987) together with geomagnetic data from the Philippine Sea basin (Hilde and Lee, 1984;
Shih, 1980) reveal a fast northward movement with significant clockwise rotation since the early Tertiary but yield no information about the longitudinal movement. The present-day motion of the Philippine Sea plate has been applied back through time to account for the Neogene tectonic events in Taiwan, Japan and the Marianas (Barrier and Angelier, 1986; Chi et al., 1981; Matsubara and Seno, 1980; Suppe, 1981, 1984), which, however, may conflict with paleomagnetic data and other geological evidence (Fuller et al., 1983; Karig. 1985; McCabe et al., 1987; Sarewitz and Karig, 1986; Seno and Maruyama, 1984). The motion of the Philippine Sea plate can apparently be divided into two stages in the last $15 \mathrm{Ma}$ (Seno and Maruyama, 1984; Sarewitz and Karig, 1986). In the Pliocene and Quaternary the plate followed the present-day mode of motion, but with a reduced (about two thirds) speed (Seno and Maruyama, 1984; Karig, 1985), whereas in the Miocene it moved rapidly (at about $7 \mathrm{~cm} / \mathrm{yr}$ at Luzon) toward the north-northwest (Sarewitz and Karig, 1986; Seno and Maruyama, 1984) with a strong (about $2^{\circ} / \mathrm{Ma}$ ) clockwise rotation (Fuller, 1985; Keating and Helsley, 1985; McCabe et al., 1987). The change of motion from north-northwesterly to west-northwesterly is believed to have taken place at around $5 \mathrm{Ma}$, as indicated by the geological information in Japan, the Marianas, Mindoro and Taiwan (Matsubara and Seno, 1980; Sarewitz and Karig, 1986; Seno and Maruyama, 1984; Teng, 1987a).

By following the motion of the Philippine Sea plate, the travel path of the Luzon arc can be backtracked, as shown in Fig. 4a. The backtracking is performed by moving the southern segment of the Luzon arc, such as Babuyan and Luzon islands, which are not yet involved in the collision (Fig. 1a). The segment of the are from Batan to Lutao, although already involved in the collision, does not appear to be significantly deformed, as shown by marine seismic data (Bowin et al., 1978; Chen and Juang, 1986). Hence, the relative position of this part of the arc with respect to Babuyan and Luzon is assumed to be unchanged. For the deformed segment in the Coastal Range of eastern Taiwan, the arc is restored by simply extending the trend of the arc for a comparable length (Fig. 

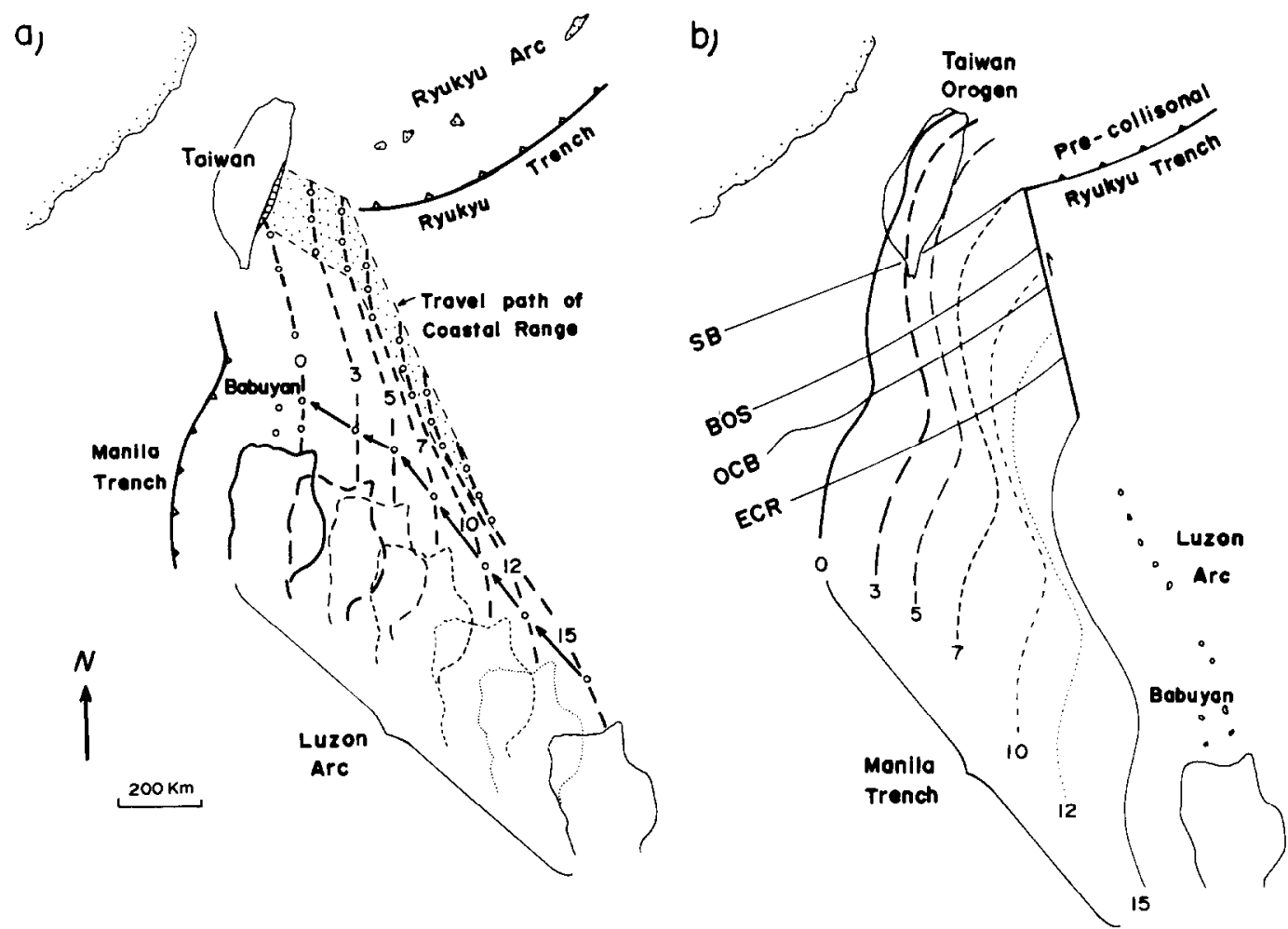

Fig. 4. Paleopositions and travel path of the Luzon arc-trench system. Numbers denote different stages in Ma. Note the change in motion at $5 \mathrm{Ma}$. (a) Luzon volcanic arc with respect to Taiwan and the Ryukyu arc-trench system. Heavy dashed lines denote the submarine traces of the Luzon volcanic arc and the stippled area shows the travel path of the northern segment of the arc that has been accreted to the collisional orogen. (b) Manila trench with respect to the pre-collisional Asian continental margin. Note the surficial deflection of the Manila trench in Taiwan from $3 \mathrm{Ma}$ to $0 \mathrm{Ma}$. Symbols and abbreviations as in Fig. 2.

4a). Based on the reconstructed Luzon volcanic arc (Fig. 4a), the paleopositions of the Manila trench can be established by extending the trace of the trench at a distance equivalent to the width of the present-day arc-trench gap (about $150 \mathrm{~km}$ ) away from the volcanic arc (Fig. 4b).

\section{Arc-continent collision}

By superimposing the paleopositions of the Luzon arc-trench system on the pre-collisional continental margin, a series of paleotectonic pictures of successive stages of arc-continent collision can be established (Figs. 4b and 5). It is clear that the Luzon arc encroached upon the continental margin obliquely, with the northern segment of the arc colliding with the continent earlier (Biq, 1973; Suppe, 1981). The northern tip of the Luzon arc might have begun overriding the continental margin sediment as early as in the Middle Miocene
(12 Ma). At about $5 \mathrm{Ma}$, the motion of the arc changed from north-northwesterly to west-northwesterly and began to override the continental margin more orthogonally and more rapidly. Both the continental margin and the arc were successively deformed by the collision from north to south and uplifted as the mountain ranges of Taiwan (Suppe, 1984; Barrier, 1985; Teng, 1987a, b). In northern Taiwan and southern Ryukyu, the change in Luzon arc motion at $5 \mathrm{Ma}$ induced westward propogation of the boundary of the subducting Philippine Sea plate and consequently extend the Ryukyu arc-trench system into northeastern Taiwan (Figs. 4b and 5) (Suppe, 1984). Meanwhile the collision at Taiwan obstructed the plate convergence at the Ryukyu trench and resulted in rifting and opening of the Okinawa trough (Lee et al., 1980; Letouzey and Kimura, 1986; Sibuet et al., 1987; Viallon et al., 1986). 


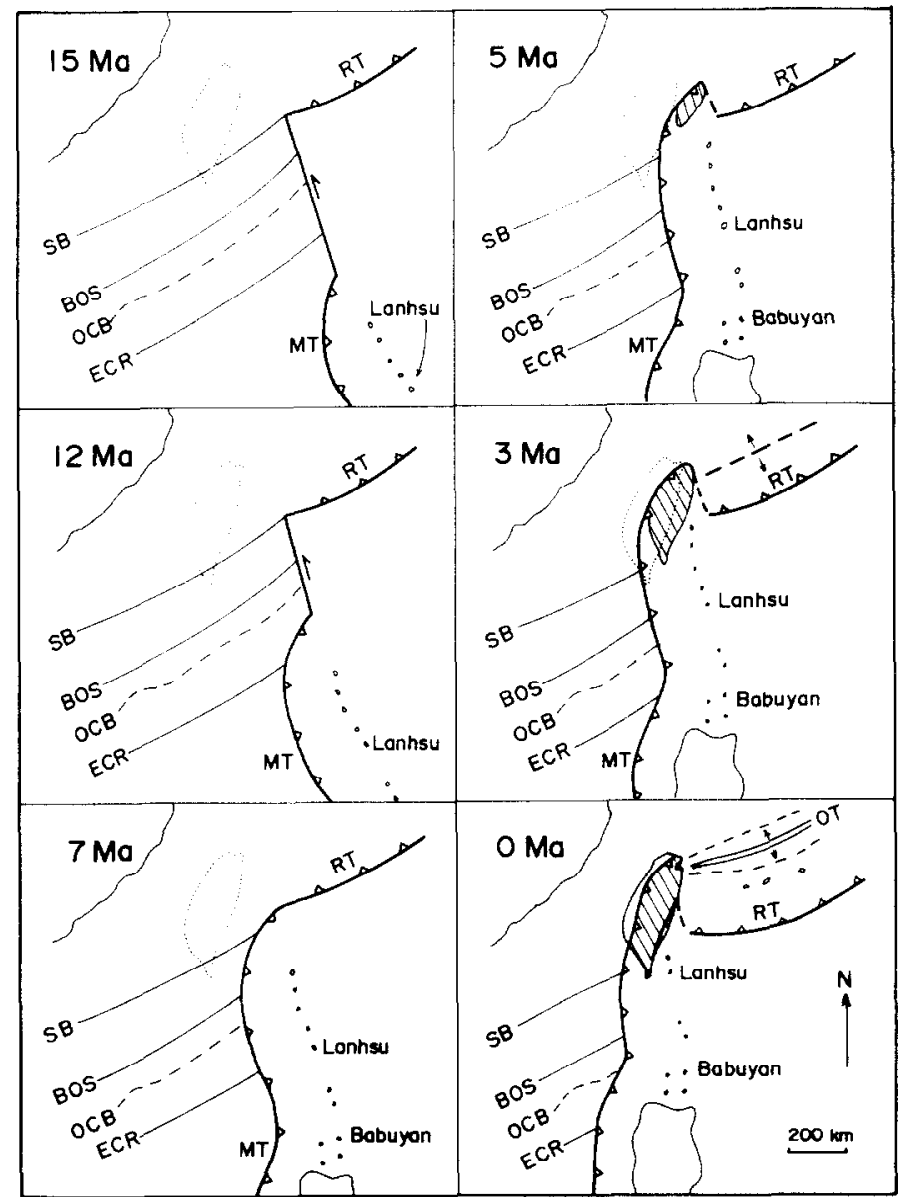

Fig. 5. Kinematics of the collision between the Luzon arc and the Asian continent. Integrated using Figs. 2 and 4. Note the opening of the Okinawa trough after $3 \mathrm{Ma}$. Shaded areas show the exposed accretionary wedge (collisional orogen) as indicated by geological data (Table 1). Symbols and abbreviations as in Fig. 2.

\section{Geological records}

Arc-continent collision has dominated the late Cenozoic magmatism, metamorphism, sedimentation and structural deformation of Taiwan (Angelier et al., 1986; Barrier and Angelier, 1986; Ernst, 1983a; Ernst and Jahn, 1987; Jahn et al., 1986; Lee and Wang, 1987; Richard et al., 1986; Suppe, 1981; Teng, 1987a). The geological history of the collision can be interpreted from the orogenic records preserved in rock sequences of the mountain ranges (Central Range) and surrounding basins (Coastal Range and Western Foothills). In this study, the orogenic records of the Coastal Range, Central Range and Western Foothills that offer essential clues and chronological constraints to the collisional events are discussed in the following.

\section{Coastal Range}

The Coastal Range comprises rocks of the precollisional Luzon arc-trench system and overlying syn-collisional orogenic sediments (Figs. $1 \mathrm{~b}$ and c) (Teng, 1987b). The collisional history can be illustrated by the composition and facies characteristics of the thick slope to deep-sea fan deposits of the forearc basin sequences (Fig. 6). The exclusive dominance of andesitic detritus in the Miocene Tuluanshan deposits indicates that the arc was situated away from continental influence (Wang, 1976). The presence of a significant amount of 


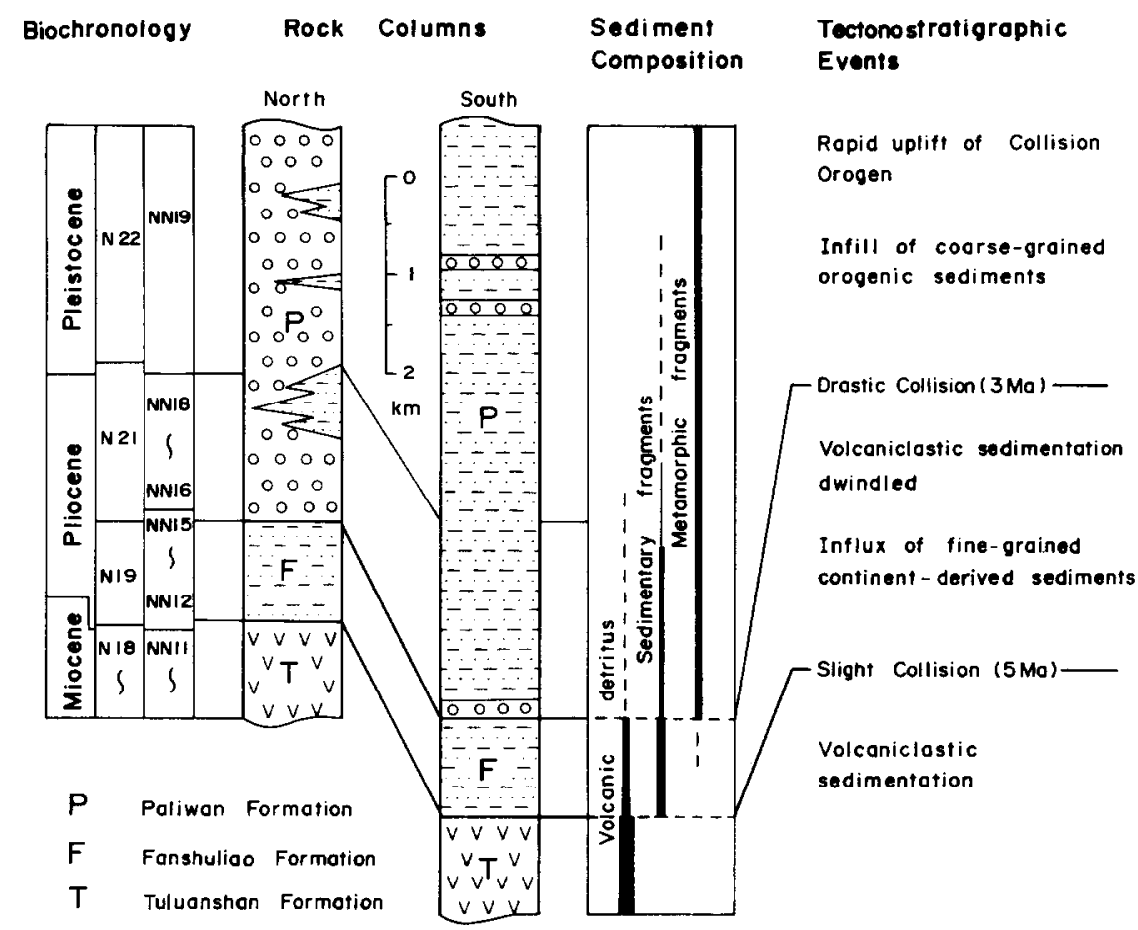

Fig. 6. Tectonostratigraphic record of the forearc basin sequence of the Coastal Range of eastern Taiwan. The stratigraphic column of the northern part is compiled from the Shuilien and Hsiukuluanchi sections and that of the southern part from the Matagida and Chengkung sections. Biochronology summarized from Chang (1967, 1968, 1969), Chang and Chen (1970), Chen (1989) and Chi et al. (1981). Rock columns and sediment composition summarized from Chen (1989), Dorsey (1988) and Teng (1979, 1987b). For lithological symbols, see Fig. 7.

fine-grained continent-derived detritus in the Lower Pliocene Fanshuliao deposits shows that the arc moved sufficiently close to receive sediment from the continent (Chen and Wang, 1988; Yao et al., 1988; Buchovecky and Lundberg, 1988; Teng, 1979, 1980). The influx of voluminous coarse-grained continent-derived sediments in the Upper Pliocene Paliwan Formation demonstrates that the continental margin was rapidly uplifted, to form high mountains (Teng, 1979, 1982). The upward increase in grain size, metamorphic grade and accumulation rate of the continent-derived sediments in the Fanshuliao-Paliwan sequences reflects not only the approach of the Luzon arc toward the continent but also the progressive uplift and unroofing of the collisional orogen (Dorsey, 1988; Dorsey et al., 1988; Teng, 1987b; Teng and Wang, 1981). The southerly fining facies character of the Paliwan deposits implies that the collisional orogen formed earlier in the north (Teng, 1982, 1988; Chen, 1989). The persistent deposition of Fanshuliao-Paliwan sediments in a deep-sea setting, however, requires continued subsidence of the forearc basin during the collision until the basin was rapidly deformed and uplifted in the late Quaternary (Lundberg and Dorsey, 1988; Teng, 1987b).

\section{Western Foothills}

The Western Foothills, as a part of the foreland fold-and-thrust belt (Ho, 1976, 1988), are underlain by thick Cenozoic siliciclastic deposits that include the Oligocene-Miocene pre-collisional continental margin sequence and the PlioceneQuaternary syn-collisional foreland basin sequence (Figs. 1b and c) (Chou, 1973; Covey, 1986; Ho, 1986; Teng, 1987a). The continental margin sequence consists of coastal to shallow-marine siliciclastic sediments derived from the granitic terrain of the Asian continent (Fig. 7) (Chai, 1972; Chou, 1973, 1980). The lateral facies variations of the continental margin sequence correspond to the original depositional settings on the continental 


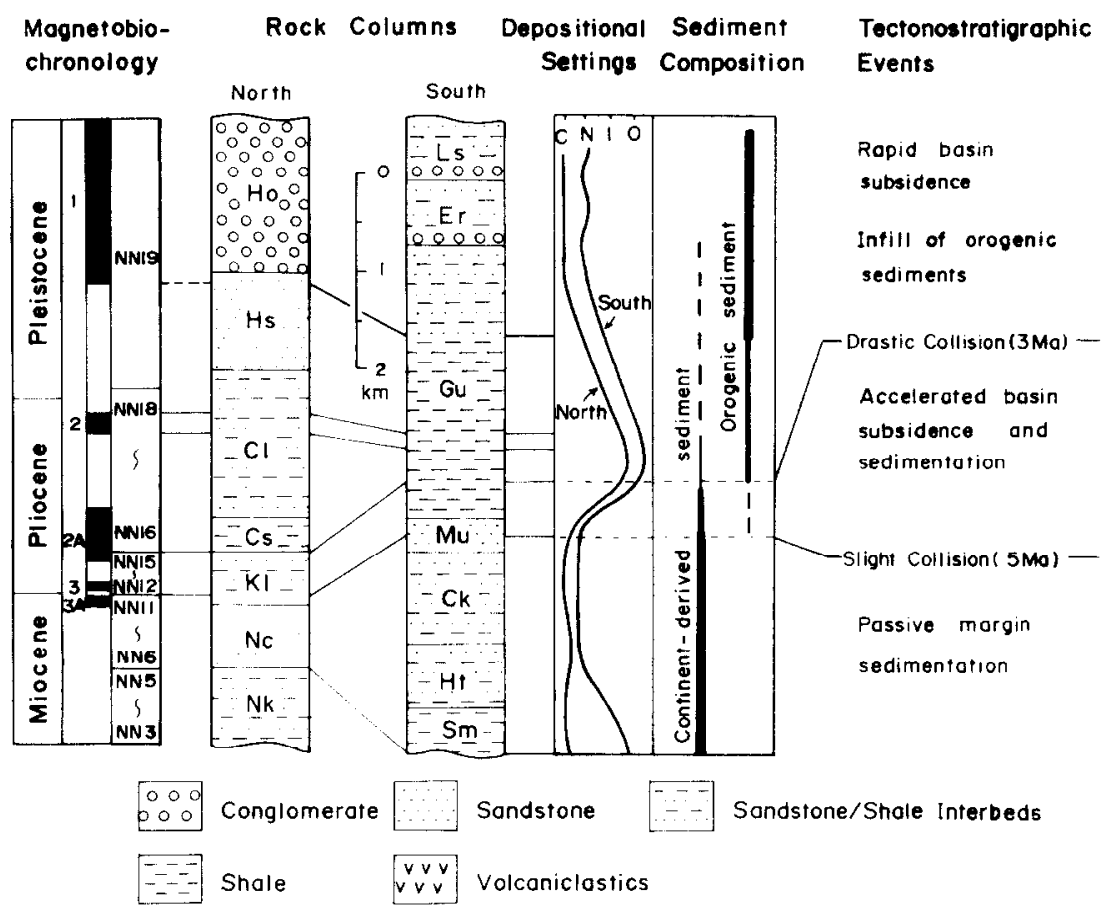

Fig. 7. Tectonostratigraphic record of the foreland basin sequence of the Western Foothills of western Taiwan. The stratigraphic column of the northern part is compiled from the Chuhuangkeng and Huoyenshan sections, and that of the southern part from the Hunghuatze and Chihshan sections. Magnetobiochronology summarized from Chen et al. (1977a, b), Chi (1979), Chi and Huang (1981), Huang (1976), Horng et al. (1989) and Lee and Lue (1984). Rock columns, depositional settings and sediment composition summarized from Chi and Huang (1981), Chou (1973, 1976, 1977, 1980), Huang (1976), Lee (1963), Lin and Hsueh (1979), Oinomikado (1955), Ting (1986), Teng (1987a) and Yu and Teng (1988). Depositional settings: $C=$ coastal; $N=$ nearshore; $I=$ inner offshore; $O=$ outer offshore. Rock units: $C k=$ Changchihkeng; $C l=$ Cholan; $C s=$ Chinshui; $E r=$ Erchungchi; $G u=G u t i n g k e n g ;$ $H o=$ Huoyenshan; $H s=$ Hsianshan; $H t=$ Hunghuatze; $K l=$ Kueichulin; $L s=$ Liushuang; $M u=$ Mucha; $N c=N a n c h u a n g ; N k=$ Nankang; $S m=$ Sanmin.

shelf (Ho, 1971; Teng, 1987a; Wang, 1987) and the vertical facies variations conform with global eustatic fluctuactions (Huang, 1982; Yu and Teng, 1988). The basin subsided slowly and smoothly, with no distinct changes in facies and composition related to the collision (Chou, 1973; Hsueh and Johns, 1985; Yu and Teng, 1988). The first indication of the collision is shown by the rapid facies change, accelerated basin subsidence, and influx of lithic sediments and reworked fossils in the Lower Pliocene foreland basin sequence, which indicates the initiation of foreland subsidence and derivation of orogenic sediments from the east (Chi and Huang, 1981; Chou, 1977; Huang, 1976; Teng, 1987a; Yu and Teng, 1988). The southerly fining facies character of the foreland basin deposits demonstrates that the collisional orogen was uplifted earlier in the north (Covey, 1984,
1986; Teng, 1987a, 1988). The upward increase in sediment grain size, sediment accumulation rate and basin subsidence rate of the Late Pliocene and Quaternary foreland basin sequence reflects the accelerated foreland subsidence and the westward progradation of orogenic sediments from the growing orogen until the basin was eventually deformed in the late Quaternary (Covey, 1986; Teng, 1987a).

\section{Central Range}

The Central Range comprises the tectonized pre-Tertiary continental basement (Tananao complex) and Cenozoic sedimentary cover (slate terrain) (Figs. 1b and c) (Chai, 1972; Ernst et al., 1985; Liou and Ernst, 1984; Suppe et al., 1976). The geological history of the Tananao Complex 
can be traced back to the Paleozoic and involves multiple crustal deformation and metamorphism in the Mesozoic and early Tertiary (Ernst, 1983a; Ernst and Jahn, 1987; Liou, 1981; Liou and Ernst, 1984). In spite of the geological complexitics, the effects of arc-continent collision can be illustrated by the late Cenozoic diastrophism of the gneiss bodies exposed in the Hoping-Chipan area (Fig. 8) which is believed to be the location of the deep-seated part of the Tananao complex (Chen et al., 1983; Wang Lee et al., 1982). According to petrological studies (Ernst, 1983b; Wang Lee et al., 1982), these gneiss bodies have been buried to a depth of about $13 \mathrm{~km}$ and subjected to upper greenschist facies metamorphism during the arccontinent collision. $\mathrm{K}-\mathrm{Ar}$ and $\mathrm{Rb}-\mathrm{Sr}$ radiometric ages of the collisional metamorphism fall mainly in the range 9-3 Ma (Jahn et al., 1986; Juang and Bellon, 1986), whereas fission-track ages of zircon and apatite center around $2 \mathrm{Ma}$ and $0.5 \mathrm{Ma}$ respectively (Liu, 1982, and unpublished data). By plotting the ages of different minerals versus their blocking temperatures and equivalent depth of burial, it is clear that the gneiss bodies were de-

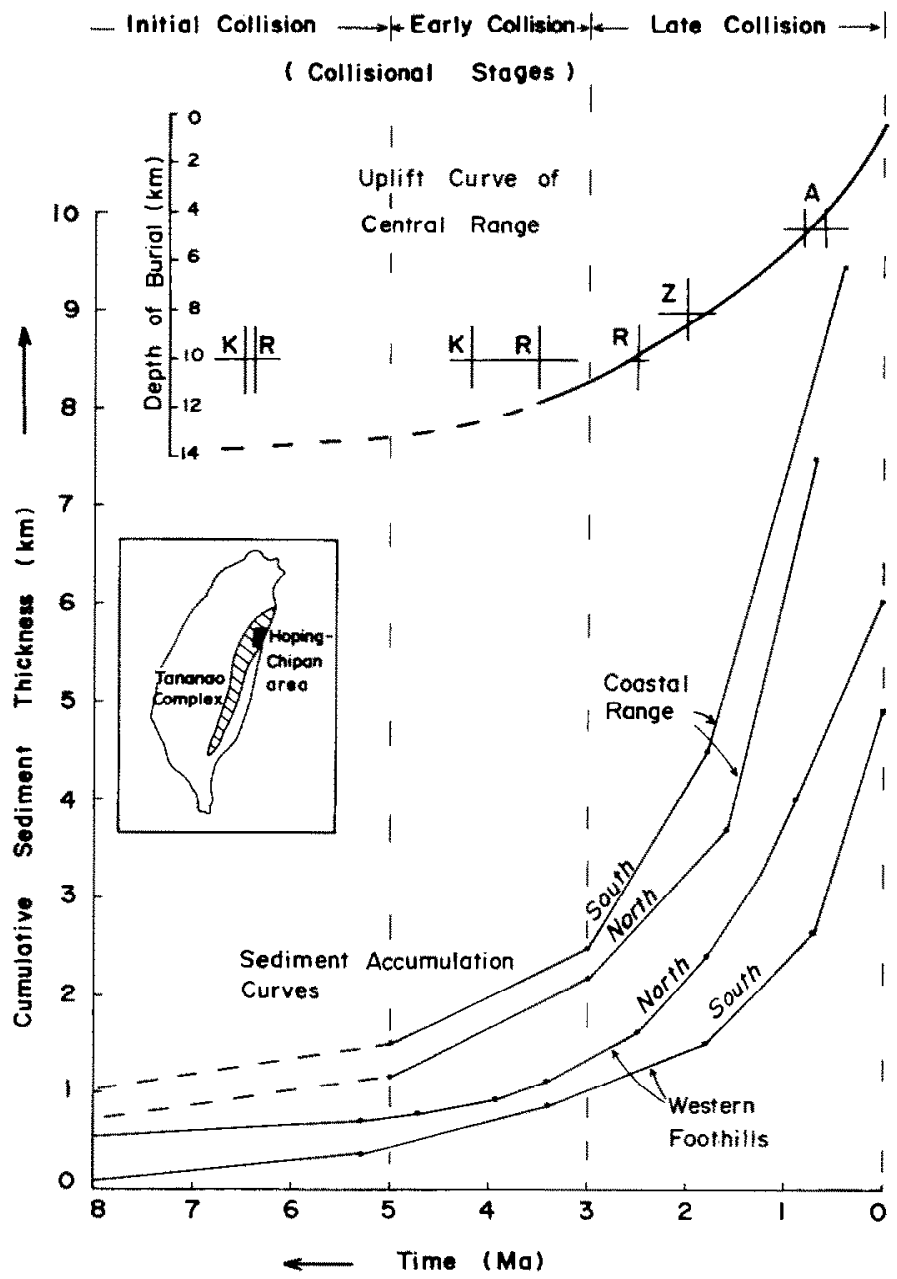

Fig. 8. Comparative curves of the uplift of the collisional orogen (Central Range) (upper part) and the sediment accumulation in the forearc (Coastal Range) and foreland (Western Foothills) basins (lower part). The uplift curve of the collisional orogen is delineated on the basis of radiometric dating of the gneiss bodies in the Hoping-Chipan area (inset). The sediment accumulation curves are established on the basis of the stratigraphic information shown in Figs. 6 and 7. Note the accelerated uplift of the collisional orogen and the increase in sediment accumulation rates in forearc and foreland basins at 5 and $3 \mathrm{Ma} . A=$ fission-track ages of apatite; 
eply buried before $3 \mathrm{Ma}$ and rapidly uplifted to the surface afterwards (Liu, 1982) (Fig. 8). A comparable burial-and-uplift history is also recorded in other parts of the Central Range (Liu, 1982, 1988), indicating that the entire Central Range was first metamorphosed at depth before 3 $\mathrm{Ma}$ and then rapidly uplifted to form the high mountains.

\section{Integrated geological records}

By integrating the geological records (Table 1), it appears that no clear orogenic effects older than $5 \mathrm{Ma}$ can be recognized either in the Coastal Range or in the Western Foothills, although part of the Central Range might have been metamorphosed. From $5 \mathrm{Ma}$ to $3 \mathrm{Ma}$, the collision not only caused intense deformation and metamorphism of the Tananao complex but also induced the foreland subsidence in the Western Foothills. Part of the continental margin might have been uplifted as the sediment source for the forearc basin of the Coastal Range, but no significant mountain ranges took shape at this time, as shown by the lack of coarse-grained orogenic sediments in the stratigraphic records (Figs. 6 and 7). At about $3 \mathrm{Ma}$, the mountain ranges of Taiwan began to rise rapidly, as shown by the uplift of the Tananao complex and the influx of voluminous orogenic sediments into the forearc and foreland basins (Fig. 8). The mountain ranges most likely took shape first in the north and then grew toward the south, as shown by the southerly fining facies pattern of the orogenic sediments (Figs. 6 and 7).

\section{Synthesis}

By incorporating geological information into plate kinematics, a geotectonic model for the late Cenozoic arc-continent collision in Taiwan can be delineated (Fig. 9). The Luzon arc, which has been moving toward the Asian continent since the Early

\section{TABLE 1}

Integrated orogenic record of late Cenozoic arc-continent collision in Taiwan

\begin{tabular}{|c|c|c|c|}
\hline $\begin{array}{l}\text { Collisional } \\
\text { (orogenic) } \\
\text { stages }\end{array}$ & $\begin{array}{l}\text { Continental margin } \\
\text { (Western Foothills) }\end{array}$ & $\begin{array}{l}\text { Accretionary wedge } \\
\text { (Central Range) }\end{array}$ & $\begin{array}{l}\text { Luzon forearc } \\
\text { (Coastal Range) }\end{array}$ \\
\hline $\begin{array}{l}\text { Late collision } \\
\text { (morphogenic stage) }\end{array}$ & Rapid deformation & $\begin{array}{l}\text { Exhumation of } \\
\text { metamorphic core }\end{array}$ & Rapid deformation \\
\hline & $\begin{array}{l}\text { Progradation of } \\
\text { orogenic sediment }\end{array}$ & Intense erosion & $\begin{array}{l}\text { Progradation of orogenic } \\
\text { sediment }\end{array}$ \\
\hline & $\begin{array}{l}\text { Rapid foreland } \\
\text { subsidence }\end{array}$ & Rapid uplift & $\begin{array}{l}\text { Influx of coarse-grained } \\
\text { orogenic sediment }\end{array}$ \\
\hline \multirow{3}{*}{$\begin{array}{l}\text { Early collision } \\
\text { (metamorphic stage) }\end{array}$} & & Intense metamorphism & \\
\hline & $\begin{array}{l}\text { Continued passive } \\
\text { margin sedimentation }\end{array}$ & Mild erosion & $\begin{array}{l}\text { Influx of fine-grained } \\
\text { continental sediment }\end{array}$ \\
\hline & $\begin{array}{l}\text { Initial foreland } \\
\text { subsidence }\end{array}$ & $\begin{array}{l}\text { Rapid growth to } \\
\text { sea level }\end{array}$ & $\begin{array}{l}\text { Volcanicalstic sedimentation } \\
\text { dwindled }\end{array}$ \\
\hline \multirow[t]{2}{*}{$\begin{array}{l}\text { Initial collision } \\
\text { (metamorphic stage) }\end{array}$} & $\begin{array}{l}\text { Passive margin } \\
\text { sedimentation }\end{array}$ & Initial metamorphism & \multirow{2}{*}{$\begin{array}{l}\text { Volcaniclastic } \\
\text { sedimentation }\end{array}$} \\
\hline & Slow subsidence & $\begin{array}{l}\text { Gradual growth below } \\
\text { sea level }\end{array}$ & \\
\hline
\end{tabular}


(a) $12 \mathrm{Ma}$
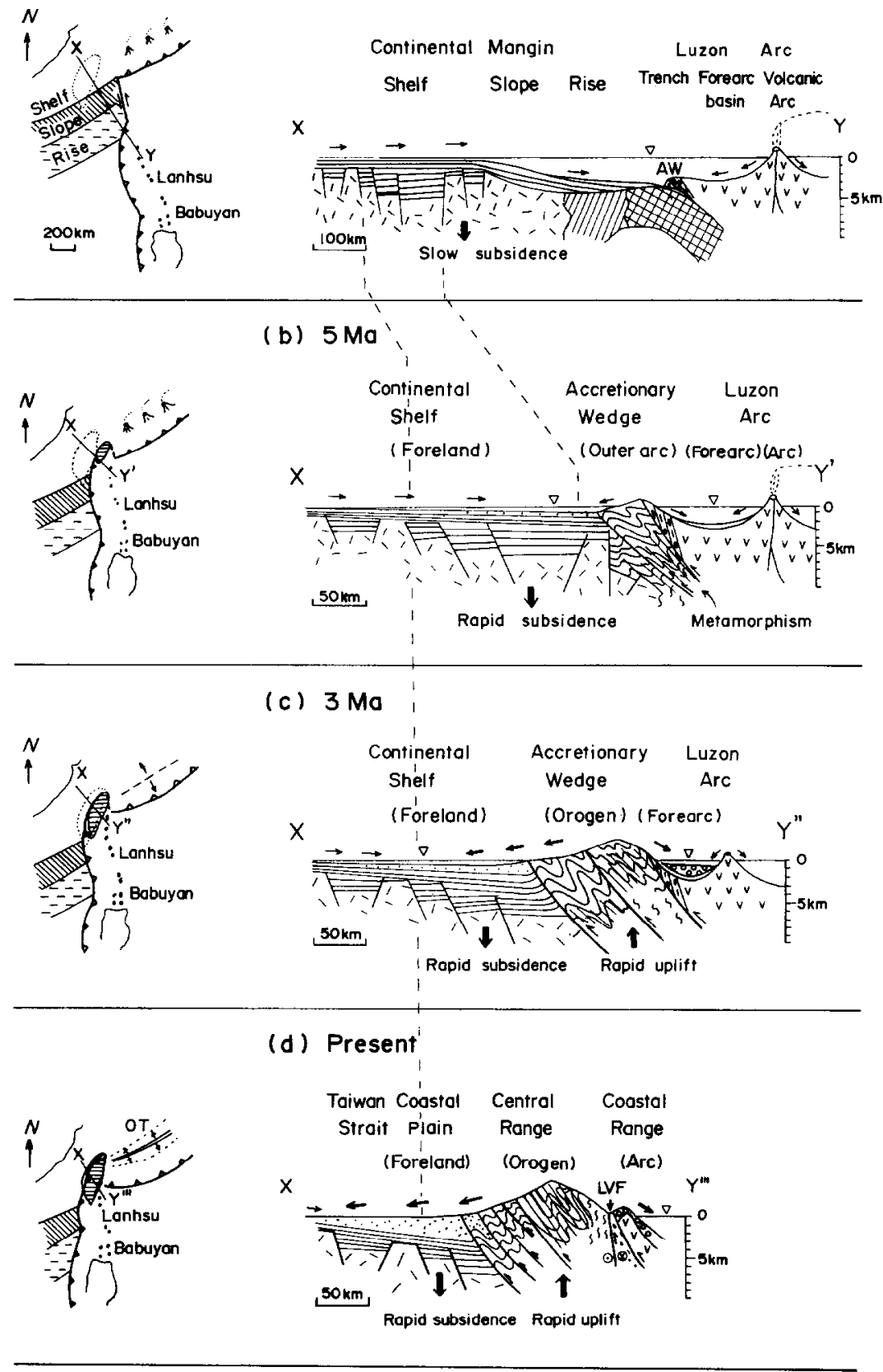

Fig. 9. Geotectonic evolution of the late Cenozoic arc-contınent collision in Taiwan. The figures on the left are collisional kinematics modified from Fig. 5 and those on the right are the corresponding schematic cross sections. Note the reduced horizontal scale of Fig. 9a compared with the others. Dashed lines connect sites for reference. Small arrows near the ground surface indicate the major sediment influx. (a) Beginning of initial collision. The northern tip of the Luzon arc began to override the continental rise. The accretionary wedge $(A W)$ remained as a submarine high but progressively grew upwards as continental materials were incorported into the subduction zone. (b) Beginning of early collision. The northern tip of the Luzon arc encroached upon the continental shelf and the accretionary wedge grew above sea level as an outer arc. Note that an appreciable amount of continental slope and rise materials has been pulled into the deep subduction zone since $12 \mathrm{Ma}$ and has become metamorphosed in the deeper part of the accretionary wedge. (c) Beginning of late collision. The accretionary wedge rapidly uplifted as mountain ranges which shed voluminous coarse-grained orogenic sediments into forearc and foreland basins. (d) The present collisional orogen of Taiwan. Note the accreton of the forearc and foreland basins to the orogen in north-central Taiwan and the ongoing accretion in southern Taiwan as well as in the areas further to the south. $L V F=$ Longitudinal Valley Fault; $O T=$ Okinawa trough. 
Miocene, did not have any contact with the continent until the late Middle Miocene (about $12 \mathrm{Ma}$ ), when the northern tip of the arc began to override the continental rise (Fig. 9a). As the Luzon arctrench system progressively encroached upon the continental margin, the continental crust and overlying sediment were either dragged deep down into the subduction zone or scraped off at the trench to add to the accretionary wedge. In the Late Miocene (10-5 Ma), the accretionary wedge grew slowly and remained as a submarine high while some of the continental materials were pulled into the deep subduction zone to become metamorphosed (Figs. 5 and 9b). In the Mio-Pliocene (about $5 \mathrm{Ma}$ ) (Fig. 9b), the Luzon arc shifted its direction of motion from north-northwest to west-northwest and an increasing amount of continental materials was incorporated into the subduction zone. The accretionary wedge at the northern end of the arc grew rapidly to emerge above sea level as an outer arc which began to shed fine-grained continental detritus to the forearc basin (Teng, 1987b). In the meantime, the impingement of the arc caused flexural bending of the continental crust to induce foreland subsidence. In spite of the intense diastrophism associated with this early stage of the collision, no significant high mountains appear to have taken shape during the Early Pliocene (5-3 Ma). In the early Late Pliocene ( $3 \mathrm{Ma}$ ) (Fig. 9c), drastic collision commenced and caused rapid uplift of the mountain ranges in northern Taiwan. Voluminous orogenic sediments were derived from the rising mountain ranges and dumped into the rapidly subsiding forearc and foreland basins (Covey, 1986; Lundberg and Dorsey, 1988; Teng, 1987a). As the oblique collision proceeded, the orogeny propogated toward the west and the south and progressively accreted the forearc and foreland basins to the collisional orogen which eventually grew up to its present configuration (Fig. 9d). In the north, a flip in subduction induced westward propogation of the Ryukyu arc-trench system and opening of the Okinawa trough since the Pliocene (Suppe, 1984). To the south, active collision and mountain building are still going on today and the tectonic events presently taking place south of Taiwan probably resemble those which occurred in Taiwan at earlier times (Suppe, 1981; Page and Suppe, 1981; Teng, 1987a).

\section{Discussion}

The geotectonic model proposed herein (Fig. 9) is established on the basis of the available plate kinematic and geological information and is thus subjected to the uncertainties associated therewith. Regarding geological records, the tectonostratigraphic records of the Coastal Range and the Western Foothills are well constrained by sedimentological and magnetobiochronological data, and the diastrophic history of the Central Range is well delineated by petrological and radiochronological data (Figs. 6,7 and 8). The consistency between the diastrophic records of the collisional orogen and the stratigraphic records of the surrounding forearc and foreland basins substantiates the validity of the interpreted orogenic history (Table 1). Regarding plate kinematics, restoration of the pre-collisional morphotectonic settings of the continental margin and the travel path of the Luzon arc involves extrapolation and this may not be as tightly constrained as the information provided by the geological data. Nevertheless, regional geophysical and geological information confines the uncertainties to a limited range such that the proposed kinematics (Figs. 4 and 5) should not be far from the truth. The model is believed to be more reliable for the Pliocene and Quaternary because of the abundant geophysical and geological constraints. For the Miocene, the model is less constrained and relies heavily on paleomagnetic data and geological interpretations.

In spite of the intrinsic uncertainties, the model provides a useful guideline for understanding the late Cenozoic orogeny in Taiwan. In addition to the aforementioned orogenic effects on metamorphism, sedimentation and uplift, the model also sheds light on other aspects of the orogeny. For instance, the onset of Pliocene-Quaternary arc magmatism and the change from compressional tectonism to extensional tectonism in northern Taiwan and southern Ryukyu can be related to the westward propagation of the Ryukyu volcanic arc and associated Okinawa trough (Kuramoto and Konishi, 1989; Lee and Wang, 1987; Suppe, 
1984; Wang, 1989). The increase in alkalinity of the volcanic rocks of the Coastal Range in the last $10 \mathrm{Ma}$ can be attributed to the incorporation of continental materials into the magma generation zone as the $\mathrm{Li}$.zon arc encroached upon the continent (Juang, and Chen, 1988; H.J. Lo and C.H. Chen, peis. commun., 1989). Possible complications in this simplified model might also have important geological implications. For instance, blocks of oceanic crust or rifted continental fragments could have heen incorporated into the subduction zone before the Luzon arc collided with the continent (Suppe et al., 1981; Suppe, 1988). Transcurrent movement associated with the oblique plate convergence might also transpose oceanic or continental blocks laterally and result in juxtaposition of incongruent terranes (Karig, 1983; Karig et al., 1986). Some of the isolated blocks and incongruent terranes could have been accreted to the collisional orogen, showing up as erratic terranes in the Tananao Complex of the Central Range (Lan and Liou, 1981; Lin et al., 1984; Liou, 1981; Wang Lee et al., 1985; Yang and Wang, 1985) or as exotic blocks in the Lichi Melange of the Coastal Range (Page and Suppe, 1981; Suppe et al., 1981).

Because Taiwan is one of the world's active collisional orogens, the information revealed by the proposed model is also useful for understanding basic mountain building processes. For instance, metamorphism associated with the collisional orogeny in Taiwan might have commenced in the Late Miocene while no orogenic effects can be recognized in the sedimentary record until the Early Pliocene (Table 1). The morphological buildup of mountain ranges ( $3 \mathrm{Ma}$ ) clearly postdates the onset of orogeny in the sedimentary record ( $5 \mathrm{Ma}$ ) by two million years (Table 1 ). The diachronous relationships between the orogeny, metamorphism and morphogenesis of the Taiwan orogen can be well accounted for by the progressive encroachment of the Luzon arc upon the Asian continent (Fig. 9), and hence provide an actualistic model for the same types of relationships that have been widely reported in ancient orogens (Gansser, 1983; Miyashiro, 1982). For other basic studies, such as the mechanical analyses attempted by Suppe (1981), Dahlen et al. (1984) and Huchon et al. (1986), the model may also provide some time-space constraints.

\section{Conclusions}

On the basis of the available geophysical and geological information, the geotectonic evolution of late Cenozoic arc-continent collision in Taiwan can be delineated by incorporating geological data into plate kinematics. The collision might have commenced in the late Middle Miocene (about 12 Ma), when the northern tip of the Luzon arc began to override the Asian continental rise. In spite of some subduction-zone metamorphism associated with the initial phase of the collision, no distinct tectonic effects can be recognized in the sedimentary record until Mio-Pliocene time (about $5 \mathrm{Ma}$ ), when the Luzon forearc basin received the continent-derived sediment and the foreland basin began to subside rapidly. Drastic collison commenced in the early Late Pliocene (about $3 \mathrm{Ma}$ ) and caused rapid uplift of the collisional orogen which shed a large amount of orogenic sediment into the forearc and foreland basins. Continued collision accreted the forearc and foreland basins to the collisional orogen which progressively grew toward the west and the south to its present configuration.

\section{Acknowledgements}

I am grateful to Profs. C. S. Ho and J. Angelier for their encouragement and great help in making this study possible. Special thanks are due to Dr. T. K. Liu for stimulating discussion and generosity in releasing unpublished data. The ideas in this paper also benefited from discussions with $\mathrm{J}$. Suppe, M. Fuller, W.S. Chen, C.S. Ho, J. Angelier, Y. Wang, W.R. Chi, P.M. Liew, H.J. Lo, T.Q. Lee, C.S. Horng, C.T. Lee and C.Y. Lu. Profs. C.S. Ho and J.Angelier and an anonymous reviewer critically read the manuscript and offered valuable comments. This study was supported by grants NSC77-0202-M002-26 and NSC79-0202-M002-05.

\section{References}

Angelier, J., Barrier, E. and Chu, H.T., 1986. Plate collision and paleostress trajectories in a fold-thrust belt: the foothills of Taiwan. Tectonophysics, 125: 161-178. 
Bachman, S.B., Lewis, S.D. and Schweller, W.J., 1983. Evolution of a forearc basin, Luzon Central Valley, Philippines. Am. Assoc. Pet. Geol. Bull., 67: 1143-1162.

Balce, G.R., Encina, R.Y., Momongan, A. and Lara, E., 1982. Geology of the Baguio district and its implication for the tectonic development of the Central Luzon Cordillera. Geol. Paleontol. Southeast Asia, 21: 265-287.

Barrier, E., 1985. The two stage collision of Taiwan: an active orogen. Tectonophysics, 115: 167-175.

Barrier, E. and Angelier, J., 1986. Active collision in eastern Taiwan: the coastal range. Tectonophysics, $125: 39-72$

Biq, C.C., 1973. Kinematic pattern of Taiwan as an example of actual continent-arc collision. Report of the Seminar on Seismology, US-ROC Coorperative Science Program. pp. 21-26.

Bosum, W., Burton, G.D., Hsieh, S.H., Kind, E.G., Schreiber, A. and Tang, C.H., 1970. Aeromagnetic survey of offshore Taiwan. UN ECAFE CCOP Tech. Bull., 3: 1-34.

Bowin, C., Lu, R.S., Lee, C.S. and Schouten, H., 1978. Plate convergence and accretion in the Taiwan-Luzon region Am. Assoc. Pet. Geol. Bull., 62: 1645-1672.

Buchovecky, E.J. and Lundberg, N., 1988. Clay mineralogy of mudstones from the southern Coastal Range, eastern Taiwan: unroofing of the orogen versus in-situ diagenesis. Acta Geol. Taiwan., 26: 247-261.

Cardwell, R.K., Isacks, B.L. and Karig, D.E., 1980. The spatial distribution of earthquakes, focal mechanism solutions, and subducted lithosphere in the Philippine and northeastern Indonesian islands. In: D.E. Hayes (Editor), The Tectonic and Geologic Evolution of Southeast Asian Seas and Islands. Am. Geophys. Union Geophys. Monogr., 23: 1-36.

Chai, B.H.T., 1972. Structure and tectonic evolution of Taiwan. Am. J. Sci., 272: 389-442.

Chang, L.S., 1967. A biostratigraphic study of the Tertiary in the Coastal Range, eastern Taiwan, based on smaller foraminifera (I, southern part). Proc. Geol. Soc. China, 10: 64-76.

Chang, L.S., 1968. A biostratigraphic study of the Tertiary in the Coastal Range, eastern Taiwan, based on smaller foraminifera (II, northern part). Proc. Geol. Soc. China, 11: 19-33.

Chang, L.S., 1969. A biostratigraphic study of the Tertiary in the Coastal Range, eastern Taiwan, based on smaller foraminifera (III, middle part). Proc. Geol. Soc. China, 12: 89-101.

Chang, L.S. and Chen, T.H., 1970. A biostratigraphic study of the Tertiary along the Hsukuluanchi in the Coastal Range. eastern Taiwan, based on smaller foraminifera. Proc. Geol. Soc. China, 13: 115-128.

Chen, C.H., Chu, H.T., Liou, J.G. and Enst, W.G., 1983. Explanatory notes for the metamorphic facies map of Taiwan. Cent. Geol. Surv. China, 2, 35 pp.

Chen, M.P. and Juang, W.S., 1986. Seafloor physiography off southeastern Taiwan. Acta Oceanogr. Taiwan., 16: 1-7.

Chen, P.H., Huang, T.C., Huang, C.Y., Jiang, M.J., Lo, S.L. and Kuo, C.L., 1977a. Paleomagnetic and coccolith stratig- raphy of Plio-Pleistocene shallow marine sediments, Chuhuangkeng, Miaoli. Pet. Geol. Taiwan, 14: 219-239.

Chen, P.H., Huang, C.Y., Huang, T.C. and Tsai, L.P., 1977b. A study of the Late Neogene marine sediments of the Chishan area, Taiwan: Paleomagnetic stratigraphy, biostratigraphy, and paleoclimate. Mem. Geol. Soc. China, 2 169-190.

Chen, W.S., 1989. Tectonic evolution of sedimentary basins in the Coastal Range, Taiwan. Ph.D. Dissert.. National Taiwan Univ., Taipei (Unpubl.).

Chen. W.S. and Wang, Y., 1988. Development of deep-sea fan systems in the Coastal Range basin, eastern Taiwan. Acta Geol. Taiwan., 26: 37-56.

Chen, W.S., Cheng, Y.M. and Huang, C.Y., 1985. Geology of the Hengchun Peninsula, southern Taiwan. Ti-Chih, $6(2)$ : $47-74$.

Chi, W.R., 1979. Calcareous nannoplankton biostratigraphy of the Hunghuatzu section, Kaohsiung area. J. Explor. Prod. Res., 2: 41-54.

Chi, W.R. and Huang, H.M., 1981. Nannobiostratigraphy and paleoenvironments of the late Neogene sediments and their tectonic implications in the Miaoli area, Taiwan. Pet. Geol. Taiwan, 18: 111-129.

Chi, W.R., Namson, J. and Suppe, J., 1981. Stratigraphic record of plate interactions in the Coastal Range of eastern Taiwan. Mem. Geol. Soc. China, 4: 155-194.

Chou, J.T., 1973. Sedimentology and paleogeography of the upper Cenozoic system of western Taiwan. Pet. Geol. Taiwan, 16: 111-143

Chou, J.T., 1976. Sedimentology and paleogeography of the Miocene clastic sequence in northern Taiwan, with emphasis on its sandstones. Pet. Geol. Taiwan, 13: 83-118.

Chou, J.T., 1977. Sedimentology and paleogeography of the Pleistocene Toukoshan Formation in western Taiwan. Pet. Geol. Taiwan, 14: 25-36

Chou, J.T., 1980. Stratigraphy and sedimentology of the Miocene in western Taiwan. Pet. Geol. Taiwan, 17: 33-52.

Covey, M., 1984. I.ithofacies analysis and basin reconstruction, Plio-Pleistocene western Taiwan foredeep. Pet. Geol. Taiwan. 20: 53-83.

Covey, M., 1986. The evolution of foreland basins to steady state: evidence from the western Taiwan foreland basin. In: P.A. Allen and P. Homewond (Editors), Foreland Basins. Int. Assoc. Sedimentol. Spec. Publ., 8: 77-90.

Dahlen, F.A., Suppe, J. and Davis, D., 1984. Mechanics of fold-and-thrust belts and accretionary wedges: Cohesive Coulomb theory. J. Geophys. Res., 89: 10087-10101.

Dorsey, R.J., 1988. Provenance evolution and unroofing history of modern arc-continent collision: evidence from petrography of Plio-Pleistocene sandstone, eastern Taiwan. J. Sediment. Petrol., 58: 208-218.

Dorsey, R.J., Buchovecky, E.J. and Lundberg, N., 1988. Clay mineralogy of Pliocene-Pleistocene mudstones, eastern Taiwan: Combined effects of burial diagenesis and provenance unroofing. Geology, 16: 944-947.

Eguchi, T. and Uyeda, S.. 1983. Seismotectonics of the Okinawa 
Trough and Ryukyu arc. Mem. Geol. Soc. China, 5: 189210.

Ernst, W.G., 1983a. Mountain building and metamorphism: a case history from Taiwan. In: K.J. Hsu (Editor), Mountain Building Processes. Academic Press, London, pp. 247-256.

Ernst, W.G., 1983b. Mineral parageneses in metamorphic rocks exposed along Tailuko Gorge, Central Mountain Range, Taiwan. J. Metamorph. Geol., 1: 305-329.

Ernst, W.G. and Jahn, B.M., 1987. Crustal accretion and metamorphism in Taiwan, a post-Palaeozoic mobile belt. Philos. Trans. R. Soc. London, Ser. A, 321: 129-161.

Ernst, W.G., Ho, C.S. and Liou, J.G., 1985. Rifting, drifting and crustal accretion in the Taiwan sector of the Asiatic continental margin. In: D.G. Howell (Editor), Tectonostratigraphic Terranes of the Circum-Pacific Region. CircumPac. Counc. Energy Miner. Resour., Houston, Tex., Vol. 1, pp. $375-389$.

Fuller, M., 1985. Paleomagnetism in an accretionary margin Luzon, northern Philippines. J. Geodyn., 2: 141-158.

Fuller, M., Dunn, J.R., Green, G., Lin, J., McCab, R., Toney, K. and Williams, I., 1980. Paleomagnetism of Truk Islands, Eastern Carolines, and of Saipan, Marianas. In: D.E. Hayes (Editor), Tectonic and Geologic Evolution of Southeast Asian Seas and Islands. Am. Geophys. Union Geophys. Monogr., 23: 235-246.

Fuller, M., McCab, R. and Williams, I.S., 1983. Paleomagnetism of Luzon. In: D.E. Hayes (Editor), The Tectonic and Geologic Evolution of Southeast Asian Seas and Islands. Part 2. Am. Geophys. Union Geophys. Monogr., 27: 79-94.

Gansser, A., 1983. The morphogenic phase of mountain building. In: K.J. Hsu (Editor), Mountain Building Processes. Academic Press, London, pp. 221-228.

Hamburger, M.W., Cardwell, R.K. and Isacks, B., 1983. Seismotectonics of the northern Philippine island arc. In: D.E. Hayes (Editor), The Tectonic and Geologic Evolution of Southeast Asian Seas and Islands. Part 2. Am. Geophys. Union Geophys. Monogr., 27: 1-22.

Haston, R., Fuller, M. and Schmidtke, E., 1988. Paleomagnetic results from Palau, West Caroline Islands: A constraint on Philippine Sea plate motion. Geology, 16: 654-657.

Hayes, D.E. and Lewis, S.D., 1984. A geophysical study of the Manila trench, Luzon, Philippines, 1. Crustal sturcture, gravity, and regional tectonic evolution. J. Geophys. Res., 89: B9171-B9195.

Hilde, T.W.C. and Lee, C.S., 1984. Origin and evolution of the West Philippine Basin: A new interpretation. Tectonophysics, 102: 85-104.

Ho, C.S., 1971. The Tertiary basins of Taiwan. Bull. Geol. Surv. Taiwan, 23: 1-52.

Ho, C.S., 1976. Foothill tectonics of Taiwan. Bull. Geol. Surv. Taiwan, 25: 9-28.

Ho, C.S., 1982. Tectonic evolution of Taiwan: Explanatory text for the tectonic map of Taiwan. Minist. Econ. Aff., Taipei, $126 \mathrm{pp}$.

Ho, C.S., 1986. A synthesis of the geologic evolution of Taiwan. Tectonophysics, 125: 1-16.
Ho, C.S., 1988. An introduction to the geology of Taiwan: Explanatory text for the geologic map of Taiwan. Minist. Econ. Aff., Taipei, 2nd ed., 164 pp.

Holloway, N., 1982. Northern Palawan Block, Philippines; its relation to mainland Asia and role in evolution of the South China Sea. Am. Assoc. Pet. Geol. Bull., 66: 13551383.

Horng, C.S., Chen, M.P., Chen, J.C. and Lee, T.Q., 1989 Correlation between the Pleistocene sequences of the Tsengwenchi and Chihshan sections. Symp. Stratigraphy of Taiwan. Cent. Geol. Surv., Taipei, pp. 38-40 (Abstr.).

Hsu, I.C., Kienzle, J., Scharon, L. and Sun, S.S., 1966. Paleomagnetic investigation of Taiwan igneous rock. Bull. Geol. Surv. Taiwan, 17: 27-81.

Hsueh, C.M. and Johns, W.D., 1985. Diagenesis of organic materials and clay minerals in the Neogene sediments of western Taiwan. Pet. Geol. Taiwan, 21: 129-172.

Huang, T.C., 1976. Neogene calcareous nannoplankton biostratigraphy viewed from the Chuhuangkeng section, northwestern Taiwan. Proc. Geol. Soc. China, 19: 7-24.

Huang, T.C., 1982. Tertiary calcareous nannofossil stratigraphy and sedimentation cycles in Taiwan. Proc. ASCOPE Conf. and Exhib., 2nd (Manila), pp. 873-886.

Huchon, P., Barrier, E., De Bremaecker, J.C. and Angelier, J., 1986. Collision and stress trajectories in Taiwan: A finite element model. Tectonophysics, 125: 179-191.

Jahn, B.M., Martineau, F., Peucat, J.J. and Cornichet, J., 1986. Geochronology of the Tananao schist complex, Taiwan, and its regional tectonic significance. Tectonophysics, 125: 103-124.

Jarrard, R.D. and Sasajima, S., 1980. Paleomagnetic synthesis for southeast Asia: Constraints on plate motions. In: D.E. Hayes (Editor). The Tectonic and Geologic Evolution of Southeast Asian Seas and Islands. Am. Geophys. Union Geophys. Monogr., 23: 293-317.

Juang, W.S. and Bellon, H., 1986. Potassium-argon ages of the Tananao schist in Taiwan. Mem. Geol. Soc. China, 7: 405-416.

Juang, W.S. and Chen, J.C., 1988. Geochronology and chemical variations in late Cenozoic volcanic rocks in Taiwan and their tectonic significance. Int. Symp. Geodynamic Evolution of the Eastern Eurasian Margin (Paris), p. 63 (Abstr.).

Karig, D.E., 1973. Plate convergence between the Philippine and the Ryukyu Islands. Mar. Geol., 14: 153-168.

Karig, D.E., 1983. Accreted terranes in the northern part of the Philippine Archipelago. Tectonics, 2: 211-236.

Karig, D.E., 1985. The framework of deformation in the Nankai Trough. In: H. Kagami, D.E. Karig, W.T. Coulbourn et al. Init. Rep. Deep-Sea Drill. Proj., 87: 927-940.

Karig, D.E., Sarewitz, D.R. and Haeck, G.D., 1986. Role of strike-slip faulting in the evolution of allochthonous terranes in the Philippines. Geology, 14: 852-855.

Keating, B.H. and Helsley, C.E., 1985. Implications of island arc rotations to the studies of marginal terranes. J. Geodyn., 2: $159-181$. 
Kimura, M., 1985. Back-are rifting in the Okinawa Trough. Mar. Petrol. Geol., 2: 222-240.

Kinoshita, H., 1980. Details of magnetic-polarity transitions recorded in sedimentary cores from the Deep Sea Drilling Project site 445, Philippine Sea. Init. Rep. Deep-Sea Drill. Proj., 58: 765-768.

Kizaki, K., 1986. Geology and tectonics of the Ryukyu islands. Tectonophysics, 125: 193-208.

Kodama, K., Keating, B.H. and Helsley, C.E., 1983. Paleomagnetism of the Bonin Islands and its tectonic significance. Tectonophysics, 95: 25-42.

Kuramoto, S. and Konishi, K., 1989. The southwest Ryukyu Arc is a migrating microplate (forearc sliver). Tectonophysics, 163: 75-91.

Lan, C.Y. and Liou, J.G., 1981. Occurrence, petrology and tectonics of serpentinites and associated rodingites in the Central Range, Taiwan. Mem. Geol. Soc. China, 4: 343-389.

Larson, E.F., Reynolds, R.L., Ozima, M., Aoki, Y., Kinoshita, H., Zasshu, S., Kawai, N., Nakajima, T., Hirooka, K., Merrill, R. and Levi, S., 1975. Paleomagnetism of Miocene volcanic rocks of Guam and the curvature of the southern Mariana island arc. Geol. Soc. Am. Bull., 86: 346-350.

Lee, C.S., 1979. Paleogene rocks of the Yushan-Shuili area, Nantou, Central Taiwan. Mem. Geol. Soc. China, 3: 237247.

Lee, C.S., Shor, G.G., Jr., Bibee, L.D., Lu, R.S. and Hilde, I., 1980. Okinawa Trough: Origin of a back-arc basin. Mar. Geol.. 35: 219-241.

Lee, C.T. and Wang, Y., 1987. Paleostress change due to the Pliocene-Quaternary arc-continent collision. Mem. Geol Soc. China, 9: 63-86.

Lee, P.J., 1963. Lithofacies of the Toukoshan-Cholan Formation of western Taiwan. Proc. Geol. Soc. China, 6: 41-50

Lee, T.Q. and Lue, Y.T., 1984. Paleomagnetic study of the Neogene sequence of the Chuhuangkeng section, Miaoli: Result of AF-demagnetization. Inst. Earth Sci., Acad. Sin., Taipei, Rep. ASIESCR8406, 31 pp.

Letouzey, J. and Kimura, M., 1986. The Okinawa through: genesis of a back-arc basin developing along a continental margin. Tectonophysics, 125: 209-230.

Lewis, S.D. and Hayes, D.E., 1983. The tectonics of northward propagating subduction along eastern Luzon, Philippine islands. In: D.E. Hayes (Editor), The Tectonic and Geologic Evolution of Southeast Asian Seas and Islands. Part 2. Am. Geophys. Union Geophys. Monogr., 27: 57-78.

Lewis, S.D. and Hayes, D.E., 1984. A geophysical study of the Manila Trench, Luzon, Philippines, 2. Forearc basin, structural and stratigraphic evolution. J. Geophys. Res., 89: 9196-9214.

Lin, M.L., Yang, C.N. and Wang, Y., 1984. Petrotectonic study of the Yuli belt of the Tananao Schist in the Chinshuichi area, eastern Taiwan. Acta Geol. Taiwan., 22: 151-188.

Lin, M.T. and Tsai, Y.B., 1981. Seismotectonics in TaiwanLuzon aera. Bull. Inst. Earth Sci., Acad. Sin., 1: 51-82.

Lin, S.B. and Hsueh, C.M., 1979. Clay mineralogy of
Pliocene-Pleistocene sedimentary rocks in the foothill region east of Lungtien, southern Taiwan. Acta Geol. Taiwan., 20: $109-128$

Liou, J.G., 1981. Petrology of metamorphosed oceanic rocks in the Central Range of Taiwan. Mem. Geol. Soc. China, 4: $291-342$

Liou, J.G. and Ernst, W.G., 1984. Summary of Phanerozoic metamorphism in Taiwan. Mem. Geol. Soc. China, 6: 133 178.

Liu, C.H. and Pan, Y.S., 1984. Seismic stratigraphic study of the Tertiary sequences in the Hsinchu basin, Taiwan. Pet Geol. Taiwan, 20: $97-112$

I.iu. T.K., 1982. Tectonic implication of fission track ages from the Central Range, Taiwan. Proc. Geol. Soc. China, 25: 22-37.

Liu, T.K., 1988. Fission track dating of the Hsueshan Range: thermal record due to arc-continent collison in Tajwan. Acta Geol. Taiwan., 26: 279-290

Liu, T.K. and Wang, Y., 1982. Expression and petrochemical implications of the western edge of subducted Philippine Sea plate underneath Taiwan. Acta Geol. Taiwan., 21: 221-229.

Louden, K.E., 1977. Paleomagnetism of DSDP sediments. phase shifting of magnetic anomalies, and rotations of the West Philippine Basin. J. Geophys. Res., 82: 2989-3002.

Lundberg, N. and Dorsey, R.J., 1988. Synorogenic sedimentation and subsidence in a Plio-Pleistocene collision basin, eastern Taiwan. In: K.L. Kleinspehn and C. Paola (Editors). New Perspective in Basin Analysis. Springer, New York. pp. $265-280$

Matsubara, Y. and Seno, T., 1980. Paleogeographic reconstruction of the Philippine Sea at 5 m.y. B.P.. Earth Planet. Sci Lett. 51: 406-414.

McCabe, R., Kikawa, E., Cole, J.T., Malicse, A.J., Baldauf, P.E., Yumul, J. and Almasco, J., 1987. Paleomagnetic results from Luzon and the Central Philippines. J. Geophys. Res., 92: 555-580.

Meng. C.Y.. 1967. The structural development of the southern half of western Taiwan. Proc. Geol. Soc. China, 10: 77-82.

Minster, J.B. and Jordan, T.H., 1979. Rotation vectors for the Philippine and Rivera plates. Eos, Trans. Am. Geophys. Union, 60: 958.

Miyashiro, A.. 1982. Theory of orogeny based on plate tectonics. In: A. Miyashiro, K. Aki and A.M.C. Sengor (Editors), Orogeny. Wiley, New York, pp. 49-119.

Oinomikado, T., 1955. Micropaleontological investigation of the Chihshan standard section, near Tainan, Taiwan. Chin. Pet. Corp. Paleontol. Lab. Rep. 7, 10 pp.

Page, B.M. and Suppe, J., 1981. The Pliocene Lichi Melange of Taiwan: its plate tectonic and olistostromal origin. Am. J. Sci., 281: 193-227.

Pelletier, B. and Hu, H.N., 1984. New structural data along two transects across the southern half of the Central Range of Taiwan. Mem. Geol. Soc. China, 6: 1-19.

Pelletier, B. and Stephan, J.F., 1986. Middle Miocene obduc- 
tion and late Miocene beginning of collision registered in the Hengchun peninsula: geodynamic implications for the evolution of Taiwan. Tectonophysics, 125: 133-160.

Ranken, B., Cardwell, R.K. and Karig, D.E., 1984. Kinematics of the Philippine Sea plate. Tectonics, 3: 555-575.

Richard, M., Bellon, H., Maury, R.C., Barrier, E. and Juang, W.S., 1986, Miocene to recent calc-alkaline volcanism in eastern Taiwan: $\mathbf{K}-\mathrm{Ar}$ ages and petrography. Tectonophysics, 125: 87-102.

Roecker, S.W., Yeh, Y.H. and Tsai, Y.B., 1987. Three dimensional $P$ and $S$ wave velocity structure beneath Taiwan. J. Geophys. Res., 92: B10547-B10570.

Ru, K. and Piggot, J.D., 1986. Episodic rifting and subsidence in the South China Sea. Am. Assoc. Pet. Geol. Bull., 70: $1136-1155$.

Sarewitz, D.R. and Karig, D.E., 1986. Processes of allochthonous terrane evolution, Mindoro Island, Philippines. Tectonics, 5: 525-552.

Seno, R., 1977. The instantaneous rotation vector of the Philippine Sea plate relative to the Eurasian plate. Tectonophysics, 42: 209-226.

Seno, R. and Eguchi, T., 1983. Seismotectonics of the western Pacific region. In: T.W.C. Hilde and S. Uyeda (Editors), Geodynamics of the Western Pacific-Indonesian Region. Am. Geophys. Union Geodyn. Ser., 11: $5-40$.

Seno, R. and Maruyama, S., 1984. Paleogeographic reconstructions and origin of the Philippine Sea. Tectonophysics, 102: 53-84.

Seno, T., Moriyama, T., Stein, S., Woods, D.F., Demets, C., Argus, D. and Gordon, R., 1987. Redetermination of Philippine Sea plate motion. Eos, Trans. Am. Geophys. Union, 68: 474.

Shih, T.C., 1980. Marine magnetic anomalies from the western Philippine sea: Implications for the evolution of marginal basins. In: D.E. Hayes (Editor), The Tectonic and Geologic Evolution of Southeast Asian Seas and Islands. Am. Geophys. Union Geophys. Monogr., 23: 49-76.

Shiono, K., Mikumo, T, and Ishikawa, Y, 1980. Tectonics of the Kyushu-Ryukyu arc as evidenced from seismicity and focal mechanism of shallow to intermediate-depth earthquakes. J. Phys. Earth, 28: 17-43.

Sibuet, J.C., Letouzy, J., Barbier, F., Charvee, J., Foucher, J.P., Hilde, T.W.C., Kimura, M., Lin-Yun, C., Marsset, B., Muller, C. and Stephan, J.F., 1987. Back arc extension in the Okinawa Trough. J. Geophys. Res., 92; 14041-14063.

Stanley, R.S., Hill, L.B., Chang, H.C. and Hu, H.N., 1981. Across section through the southern Central Mountains of Taiwan. Mem. Geol. Soc. China, 4: 44-74.

Stephan, J.F., Blanchet, R., Rangin, C., Pelletier, B., Letouzey, J. and Muller, C., 1986. Geodynamic evolution of the Taiwan-Luzon-Mindoro belt since the Late Eocene. Tectonophysics, 125: 245-268.

Sun, S.C., 1982. The Tertiary basins of offshore Taiwan. Proc. ASCOPE Conf. and Exhib., 2nd (Manila), pp. 125-135.

Sun, S.C., 1985. The Cenozoic tectonic evolution of offshore Taiwan. Energy, 10: 421-432.

Sun, S.C., 1989. Some geologic features determined on the northwest half of the southernmost Okinawa trough. Programme Abstr. ROC-ROK Semin. Oceanogr., 3rd (Taipei), p. 58.

Sung, Q.C., 1987. Stratigraphic and paleoenvironmental study of the late Neogene series in the Hengchun Peninsula. Ph.D. Dissert., National Taiwan Univ., Taipei, 160 pp. (Unpubl.).

Suppe, I., 1980a. Imbricated structure of Western Foothills Belt, south-central Taiwan. Pet. Geol. Taiwan, 17:1-16.

Suppe, J., 1980b. A retrodeformable cross section of northern Taiwan. Proc. Geol. Soc. China, 23: 46-55.

Suppe, J., 1981. Mechanics of mountain-building and metamorphism in Taiwan. Mem. Geol. Soc. China, 4: 67-90.

Suppe, J., 1984. Kinematics of arc-continent collision, flipping of subduction, and back-arc spreading near Taiwan. Mem. Geol. Soc. China, 6: 21-34.

Suppe, J., 1988. Tectonics of arc-continent collison on both sides of the South China Sea: Taiwan and Mindoro. Acta Geol. Taiwan., 26: 1-18.

Suppe, J., Wang, Y., Liou, J.G. and Ernst, W.G., 1976. Observations of some contacts between basement and Cenozoic cover in the Central Mountains, Taiwan. Proc. Geol Soc. China, 19: 59-70.

Suppe, J., Liou, J.G. and Ernst, W.G., 1981. Paleogeographic origins of the Miocene East Taiwan Ophiolite. Am. J. Sci. 281: $228-246$.

Tang, C.H., 1977. Late Miocene erosional unconformity of the subsurface Peikang High beneath the Chiryi-Yunlin coastal plain, Taiwan. Mem. Geol. Soc. China, 2: 155-168.

Taylor, B. and Hayes, D.E., 1980. The tectonic evolution of the South China Basin. In: D.E. Hayes (Editor), The Tectonic and Geologic Evolution of Southeast Asian Seas and Islands. Am. Geophys. Union Geophys. Monogr., 23: 89-104

Taylor, B. and Hayes, D.E., 1983. Origin and history of the south China basin. In: D.E. Hayes (Editor), The Tectonic and Geologic Evolution of Southeast Asian Seas and Islands. Part 2. Am. Geophys. Union Geophys. Monogr., 27: 23-56.

Teng, L.S., 1979. Petrographical study of the Neogene sandstones of the Coastal Range, eastern Taiwan (I, northern part). Acta Geol, Taiwan., 20: 129-155.

Teng, L.S., 1980. Lithology and provenance of the Fanshuliao Formation, northern Coastal Range, eastern Taiwan. Proc Geol. Soc. China, 23: 118-129.

Teng, L.S., 1982. Stratigraphy and sedimentation of the Suilien Conglomerate, northern Coastal Range, eastern Taiwan. Acta Geol. Taiwan., 21: 201-220.

Teng, L.S., 1986. Plate tectonic model of the Penglai Orogeny. Proc. Semin. Geophysics of the Taiwan Region. National Central Univ., Chungli, pp. 277-288.

Teng, L.S., 1987a. Stratigraphic records of the late Cenozoic Penglai orogeny of Taiwan. Acta Geol. Taiwan., 25: 205224.

Teng, L.S., 1987b. Tectonostratigraphic facies and geologic evolution of the Coastal Range, eastern Taiwan. Mem. Geol. Soc. China, 8: 229-250.

Teng, L.S., 1988. Late Cenozoic tectonostratigraphic evolution 
of arc-continent collision in Taiwan. Symp. Geodynamic Evolution of the Eastern Eurasian Margin (Paris), p. 101 (Abstr.).

Teng, L.S. and Wang, Y., 1981. Island arc system of the Coastal Range, eastern Taiwan. Proc. Geol. Soc. China, 24: 99-112.

Ting, H.H., 1986. Paleoenvironmental analysis of the late Neogene sequences of the Hiaolin-Mintsu area in the Western Foothills, southern Taiwan. M.S. Thesis, National Taiwan Univ., Taipei, 136 pp. (Unpubl.).

Tsai, Y.B., 1978. Plate subduction and the Plio-Pleistocene orogeny in Taiwan. Pet. Geol. Taiwan, 15: 1-10.

Tsai, Y.B., 1986. Seismotectonics of Taiwan. Tectonophysics, 125: $17-38$

Tsai, Y.B., Teng, T.L., Chiu, J.M. and Liu, H.L., 1977. Tectonic implications of the seismicity in the Taiwan region. Mem. Geol. Soc. China, 2: 13-42.

Tsai, Y.B., Liaw, Z.S., Lee, T.Q., Lin, M.T. and Yeh, Z.H., 1981. Seismological evidence of an active plate boundary in the Taiwan area. Mem. Geol. Soc. China, 4: 143-154.

Viallon, C., Huchon, P. and Barrier, E., 1986. Opening of the Okinawa basin and collision in Taiwan: A retreating trench model with lateral anchoring. Earth Planet. Sci. Lett., 80: $145-155$.

Wang, C.S., 1976. The Lichi Formation of the Coastal Range and arc-continent collision in eastern Taiwan. Bull. Geol. Surv. Taiwan, 25: 73-86.

Wang, W.S., 1989. Volcanic geology and fission-track dating of the Tatun Volcano Group of northern Taiwan. M.S. Thesis, National Taiwan Univ., Taipei, 154 pp. (Unpubl.).
Wang, Y., 1987. Continental margin rifting and Cenozoic tectonics around Taiwan. Mem. Geol. Soc. China, 9: 227 240.

Wang Lee, C., Wang, Y., Yen, T.P. and Lo, C.H., 1982. Polymetamorphism in some gneiss bodies, Hoping-Chipan area, Hualien, eastern Taiwan. Acta Geol. Taiwan., 21: $122-139$

Wang Lee, C., Chen, C.H., Wang, Y., Yui, T.F., Lu, C.Y. and Lo, C.H., 1985. Relics of ancient oceanic crust in the Changchung Formation of eastern Taiwan. Acta Geol. Taiwan., 23: 122-139.

Wu, F.T., 1978. Recent tectonics of Taiwan. J. Phys. Earth, 26: s265-s299 (Suppl.).

Yang, C.N. and Wang, Y.. 1985. Petrotectonic study of the Yuli belt of the Tananao Schist in the Juisui area, eastern Taiwan. Acta Geol. Taiwan., 23: 135-180.

Yao, T.M., Tien, P.L. and Wang-Lee, C., 1988. Clay mineralogical studies on the Neogene formations, Taiyuan Basin southern Coastal Range of Taiwan. Acta Geol. Taiwan. 26: $236-278$

Yen, T.P.. Wu. C.S. and Chuang, T.Y.. 1984. Geology of a transect across the new central cross-mountain road (the Yushan Pass), Taiwan. Mem. Geol. Soc. China, 6: 357-367.

Yu, M.S. and Teng, L.S., 1988. Neogene-Quaternary basin subsidence of northwestern Taiwan as revealed by geohistory analysis. Proc. Taiwan Symp. Geophys., 2nd. Inst. Earth Sci., Acad. Sin., Taipei, pp. 355-363. 